CORAL WHISPERERS 
CRITICAL ENVIRONMENTS: NATURE, SCIENCE, AND POLITICS

Edited by Julie Guthman, Jake Kosek, and Rebecca Lave

The Critical Environments series publishes books that explore the political forms of life and the ecologies that emerge from histories of capitalism, militarism, racism, colonialism, and more.

I. Flame and Fortune in the American West: Urban Development, Environmental Change, and the Great Oakland Hills Fire, by Gregory L. Simon

2. Germ Wars: The Politics of Microbes and America's Landscape of Fear, by Melanie Armstrong

3. Coral Whisperers: Scientists on the Brink, by Irus Braverman 


\title{
CORAL WHISPERERS
}

SCIENTISTS ON THE BRINK

\author{
Irus Braverman
}

日 UNIVERSITY OF CALIFORNIA PRESS 
University of California Press, one of the most distinguished university presses in the United States, enriches lives around the world by advancing scholarship in the humanities, social sciences, and natural sciences. Its activities are supported by the UC Press Foundation and by philanthropic contributions from individuals and institutions. For more information, visit www.ucpress,edu.

University of California Press

Oakland, California

(C) 2018 by Irus Braverman

Library of Congress Cataloging-in-Publication Data

Names: Braverman, Irus, 1970- author.

Title: Coral whisperers : scientists on the brink / Irus Braverman.

Description: Oakland, California : University of California Press, [2018] | Includes bibliographical references and index.

Identifiers: LCCN 2018008708 (print) | LCCN 2018013586 (ebook) | ISBN 9780520970830 (epub and ePDF) | ISBN 9780520298842 (cloth : alk. paper)| ISBN 9780520298859 (pbk. : alk. paper)

Subjects: LCSH: Marine scientists-Interviews. | Coral reef management. | Coral bleaching-2Ist century.

Classification: LCC GC30.AI (ebook) | LCC GC3O.AI B73 2018 (print) | DDC 577.7/89-dc23

LC record available at https://lccn.loc.gov/2018008708

https://lccn.loc.gov/2018008708

Manufactured in Canada

$\begin{array}{lllllllll}26 & 25 & 24 & 23 & 22 & 21 & 20 & \text { I9 } & \text { I8 }\end{array}$

$\begin{array}{llllllllll}\text { IO } & 9 & 8 & 7 & 6 & 5 & 4 & 3 & 2 & \text { I }\end{array}$ 
For Ruth Gates 
The publisher and the University of California Press Foundation gratefully acknowledge the generous support of the Ralph and Shirley Shapiro Endowment Fund in Environmental Studies. 